\title{
Effect of Age on the Frequency, Cell Cycle, and Lineage Maturation of Rhesus Monkey (Macaca mulatta) $\mathrm{CD34}^{+}$and Hematopoietic Progenitor Cells
}

\author{
C. CHANG I. LEE, MISTY D. FLETCHER, AND ALICE F. TARANTAL \\ California National Primate Research Center [C.C.I.L., M.D.F., A.F.T.] and Department of Pediatrics \\ [A.F.T.], University of California, Davis, Davis, California 95616
}

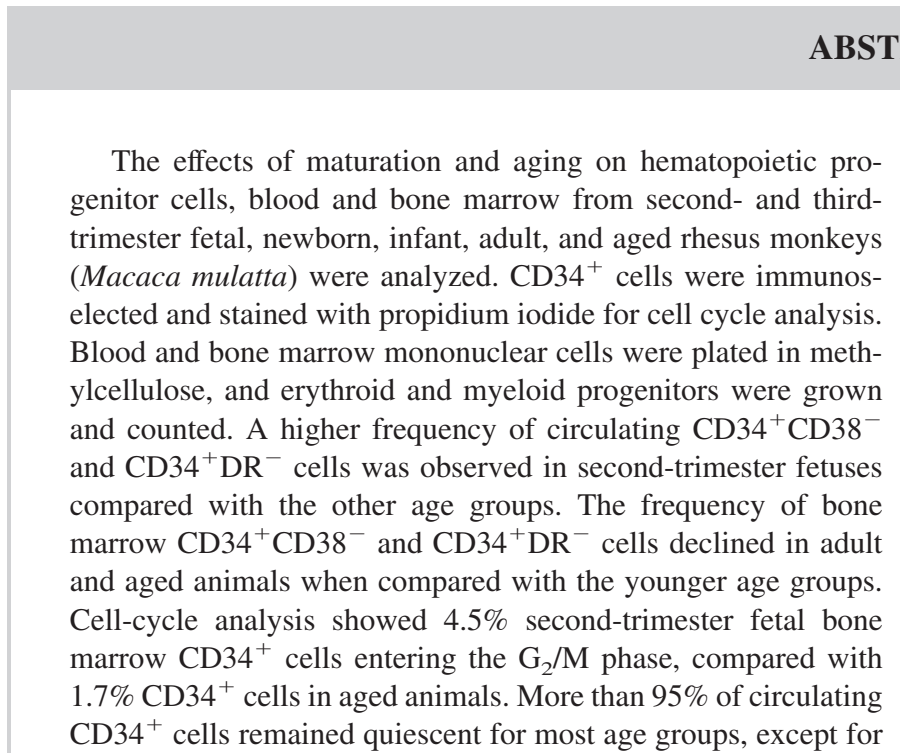

Somatic cells possess a limited ability for self-renewal, as described in the study of cellular aging by Hayflick (1). This intrinsic capability or "Hayflick limit" of cell division, also described as self-renewal potential and proliferation of somatic cells, is believed to decline in chronologically older cells (2). Unlike somatic cells, CD $34^{+}$hematopoietic stem cells (HSCs) are a long-lived population that can sustain blood cell production for the lifetime of an individual. A balance among selfrenewal, proliferation, differentiation, and migration of pluripotent HSCs is the hallmark of hematopoiesis. For example, Andrews et al. (3) showed that the $\mathrm{CD} 4^{+}$population, which contains HSCs, is responsible for hematopoietic reconstitution of lethally irradiated baboons, whereas others have shown that a small number of HSCs from the bone marrow of C57BL/6 mice can repopulate lymphohematopoietic tissues of irradiated

Received July 22, 2004; accepted January 5, 2005.

Correspondence: Alice F. Tarantal, Ph.D., California National Primate Research Center, University of California, Pedrick and Hutchison Roads, Davis, CA 95616-8542; e-mail: aftarantal@primate.ucdavis.edu.

These studies were supported by National Institutes of Health Grants HL69748 and RR00169.

DOI: 10.1203/01.PDR.0000169975.30339.32 second-trimester fetuses. Adult marrow myeloid progenitors were found in a lower quantity when compared with thirdtrimester fetuses, whereas erythroid progenitors were greatest in early-gestation fetuses and adults. The results of these studies suggest that 1 ) the greatest quantity of $\mathrm{CD} 34^{+} \mathrm{CD} 38^{-}$and $\mathrm{CD} 34^{+} \mathrm{DR}^{-}$cells was found in fetal and infant bone marrow, 2) the frequency of cycling $\mathrm{CD} 34^{+}$cells declines with maturation and aging, and 3) an age-dependent difference in lineage commitment occurs. (Pediatr Res 58: 315-322, 2005)
Abbreviations
BFU-E, burst-forming unit-erythroid
CBC, complete blood count
CFU, colony-forming unit
HSC, hematopoietic stem cell
MNC, mononuclear cell

animals (4,5). However, in mouse studies, a greater quantity of HSCs was required for reconstitution when donor HSCs were obtained from older versus younger mice. In similar studies, HSCs that were obtained from fetal liver have shown greater long-term repopulating capability when compared with HSCs from adult marrow. HSCs from DBA/2, BALB/c, and CBA/ CaH-T6 mice indicate a significant functional decline with advancing age (6-11), and transplant studies suggest that murine HSCs from a single donor can be serially transplanted only to five to seven recipients (12-14). These observations suggest that HSCs may possess finite self-renewal capabilities and are subject to the Hayflick limit.

A recent stochastic study on the replication, apoptosis, and differentiation of HSCs has revealed that mouse, cat, and nonhuman primate HSCs are biologically different in their intrinsic capabilities and that findings in the mouse may not represent in vivo behavior of HSCs in large animals or humans (15). Other studies in baboons and cats concur with this observation (6,16-18). Studies with CD34 ${ }^{+}$HSCs from largeanimal models have shown that a large fraction of these cells remain quiescent during steady-state conditions, whereas more 
rapid cycling of HSCs has been observed in mice $(15,19,20)$. Therefore, insights into the behavior of nonhuman primate HSCs and progenitor cells can contribute to a better understanding of human hematopoietic cells and their potential uses for cell- and gene-based therapies.

The goal of this study was to determine whether the quantity and the quality of $\mathrm{CD} 34^{+}$and hematopoietic progenitor cells changes with maturation and aging in rhesus monkeys. The results of these investigations suggest that the greatest relative quantity of $\mathrm{CD} 34^{+} \mathrm{CD} 38^{-}$and $\mathrm{CD} 34^{+} \mathrm{DR}^{-}$cells is found in fetal and infant bone marrow and that the frequency of cycling $\mathrm{CD} 4^{+}$cells and differentiation toward a myeloid lineage declines with advancing age.

\section{METHODS}

Animals. All animal procedures conformed to the requirements of the Animal Welfare Act, and protocols were approved before implementation by the Institutional Animal Care and Use Committee at the University of California at Davis. A total of 25 animals were included in this study, ranging from second- and third-trimester fetuses $(90,120$, and $140 \mathrm{~d}$ gestation; term $165 \pm$ $10 \mathrm{~d} ; n=9)$, newborns and infants $(n=8)$, and adult and aged animals $(n=$ 8; Table 1). All gravid adults $(n=17)$ that were included to obtain fetuses, newborns, and infants as noted above were examined sonographically during gestation to confirm normal fetal growth and development (21). Second- (90 d gestation) and third-trimester (120 and $140 \mathrm{~d}$ gestation) fetuses were delivered by hysterotomy, and newborns were delivered by cesarean-section at term then raised in the nonhuman primate nursery, using established techniques (22).

Sample collection and immunostaining. Blood samples $(4-10 \mathrm{~mL})$ were collected for complete blood counts (CBCs; $250 \mu \mathrm{L})$, flow cytometry $(1 \mathrm{~mL})$, immunoselection $(2-5 \mathrm{~mL})$, and hematopoietic progenitor assays $(1 \mathrm{~mL})$ by fetal cardiocentesis, from the umbilical cord at the time of delivery of newborns, or from a peripheral vessel (infants, adults, and aged animals), as previously described (23). Fetal bone marrow was collected from the long bones (humerus, femur, tibia/fibula, and radius/ulna) by flushing with heparinized RPMI at tissue harvest, using established techniques (23). Collected cells were filtered through Falcon 40- $\mu \mathrm{m}$ Nylon cell strainers (Fisher Scientific, Pittsburgh, PA). Bone marrow $(2-5 \mathrm{~mL})$ was aspirated under aseptic conditions from newborn, infant, adult, and aged monkeys under ketamine (10 $\mathrm{mg} / \mathrm{kg}$ ) and local lidocaine, as previously described (22). A total of $80 \mu \mathrm{L}$ of whole blood and bone marrow was stained with CD34 MAb (clone 563-PE; BD PharMingen, San Diego, CA) and lineage-specific markers, including CD3 (clone SP34-2-PerCP; BD PharMingen), CD14 (clone M $\varphi$ P9-FITC; BD Immunocytometry Systems, San Jose, CA), CD16 (clone 3G8-FITC; BD PharMingen), CD20 (clone L27-FITC; BD Immunocytometry Systems), CD38 (clone OKT10-FITC; American Type Culture Collection, Manassas, VA), CD45 (clone Tü116; BD PharMingen), and HLA-DR (clone G46-6; BD PharMingen), for $20 \mathrm{~min}$ at room temperature. Red blood cells were lysed using the Coulter Q-Prep (Beckman Coulter, Fullerton, CA). A FACSCalibur flow cytometry system (Becton-Dickinson, San Jose, CA) was used for these studies. Isotype control IgG was used as a negative control (Exalpha Corp.,

Table 1. Overview of rhesus monkeys (Macaca mulatta) included in the study

\begin{tabular}{llcr}
\hline \multicolumn{1}{c}{ Group (N) } & \multicolumn{1}{c}{ Age } & \multicolumn{1}{c}{ Sex } & \multicolumn{1}{c}{ Body weight } \\
\hline Fetal (9) & $90 \mathrm{~d} \mathrm{(3)*}$ & $2 \mathrm{~F}, 1 \mathrm{M}$ & $94.84 \pm 3.03 \mathrm{~g}$ \\
& $120 \mathrm{~d} \mathrm{(3)*}$ & $3 \mathrm{M}$ & $257.72 \pm 14.40 \mathrm{~g}$ \\
& $140 \mathrm{~d}(3)^{*}$ & $1 \mathrm{~F}, 2 \mathrm{M}$ & $395.58 \pm 12.66 \mathrm{~g}$ \\
Newborn (4) & Birth & $1 \mathrm{~F}, 3 \mathrm{M}$ & $408.23 \pm 11.06 \mathrm{~g}$ \\
Infant (4) & $6 \mathrm{~m}$ & $2 \mathrm{~F}, 2 \mathrm{M}$ & $1.52 \pm 0.06 \mathrm{~kg}$ \\
Adult (4) & $7-14 \mathrm{y}$ & $4 \mathrm{~F} \ddagger$ & $7.93 \pm 0.86 \mathrm{~kg}$ \\
Aged (4) & $23-26 \mathrm{y}$ & $4 \mathrm{~F} \S$ & $10.21 \pm 0.54 \mathrm{~kg}$ \\
\hline
\end{tabular}

* Gestational age. $90 \mathrm{~d}=$ second trimester and 120 and $140 \mathrm{~d}=$ third trimester; term $165 \pm 10 \mathrm{~d} . \mathrm{F}=$ female; $\mathrm{M}=$ male; no significant differences were observed between females and males, therefore all data were grouped by age.

$\ddagger$ All animals displayed normal menstrual cycles.

$\S 1$ of 3 with irregular menstrual cycles, and 2 of 3 were post-menopausal.
Boston, MA). Mononuclear cells (MNCs) were gated by their forward- and side-scatter characteristics to exclude contaminating red blood cells, granulocytes, and monocytes. A minimum of $1 \times 10^{4}$ cells were analyzed for each sample. All $\mathrm{CD} 34^{+}$cells that were analyzed were also positive for CD45, confirming hematopoietic origin (data not shown).

Immunomagnetic selection of $\mathrm{CD}^{+} 4^{+}$cells. $\mathrm{CD} 34^{+}$cells from blood and bone marrow were selected using the mini-MACS immunomagnetic separation system (Miltenyi Biotec, Bergisch Gladbach, Germany). MNCs $\left(1 \times 10^{7}\right)$ were suspended in selection buffer (0.5\% BSA and 2 mM EDTA in PBS) and incubated with anti-CD32 nonspecific blocking immunoglobulin to FcRIIA for $10 \mathrm{~min}$ at $4^{\circ} \mathrm{C}$, followed by a 20-min incubation with CD34 MAb (clone 563; StemCell Technologies, Vancouver, BC, Canada) at $4^{\circ} \mathrm{C}$. Cells were washed with $5 \mathrm{~mL}$ of selection buffer and centrifuged at $400 \times g$ for $5 \mathrm{~min}$. The pellet was resuspended in selection buffer that contained magnetic colloids (StemCell Technologies) and incubated for $30 \mathrm{~min}$ at $4{ }^{\circ} \mathrm{C}$. Cells were washed and resuspended in $500 \mu \mathrm{L}$ of selection buffer, then applied to separation columns. Separation columns were washed three times, and retained cells were eluted with $1 \mathrm{~mL}$ of selection buffer. A second round of separation was performed on the eluted cells. Purity of selected CD $34^{+}$cells was $97.01 \pm 1.32 \%$.

Cell-cycle analysis. Cell-cycle characteristics of immunoselected CD $34^{+}$ cells from blood and bone marrow were determined by propidium iodide DNA staining. Cells were washed, and $4.5 \mathrm{~mL}$ of $70 \%$ ethanol then was added to each pellet. Cells were stored at $0-4^{\circ} \mathrm{C}$ for at least $2 \mathrm{~h}$ before staining, then centrifuged for $5 \mathrm{~min}$; the ethanol was decanted; and the cell pellet was resuspended in $5 \mathrm{~mL}$ of PBS and centrifuged again after $1 \mathrm{~min}$. The cell pellet was resuspended in propidium iodide [Sigma Chemical Co., St. Louis, MO; 0.5 $\mathrm{mg} / \mathrm{mL}$ PBS with 0.1 sodium azide, ( $\mathrm{pH} 7.4) ; 20$ units $/ \mathrm{mL}$ RNaseA; and $0.1 \%$ wt/vol Triton X-100]. Stained CD34 $4^{+}$cells then were incubated at $37^{\circ} \mathrm{C}$ for 15 $\mathrm{min}$, and cell fluorescence was examined by flow cytometry. A minimum of 2 $\times 10^{4}$ cells were analyzed from each sample, and the percentage of cells within the $G_{0} / G_{1}, S$, and $G_{2} / M$ phases was determined using the ModFit software program (Verity Software, Topsham, ME).

Hematopoietic progenitor assay. Hematopoietic progenitor assays were performed on MNCs, as previously described (22). Briefly, MNCs from blood and bone marrow were isolated with density gradient centrifugation using Histopaque (Sigma Chemical Co.). The cells were resuspended in RPMI, then washed. A total of $5 \times 10^{4}$ cells/plate (six plates, $3 \times 10^{5} \mathrm{MNC}$ ) from blood and $2 \times 10^{4}$ cells/plate (four plates, $8 \times 10^{4} \mathrm{MNC}$ ) from bone marrow were plated in $1 \mathrm{~mL}$ of MethoCult GF+ H4435 that contained human erythropoietin, granulocyte colony-stimulating factor, granulocyte-macrophage colonystimulating factor, stem cell factor, IL-3, and IL-6 (StemCell Technologies) in fibroblast-free 35-mm culture plates. Erythroid and myeloid progenitor colonies were counted after a standardized 10-d incubation period (22).

Statistical analysis. Results that were obtained from experiments were reported as the mean \pm SEM and calculated using Apple Macintosh systems with statistical software (StatView 5.0.1; Brainpower, Calabasas, CA). Statistical significance $(p<0.05)$ was determined by ANOVA or two-sided $t$ test.

\section{RESULTS}

In this study, we measured the relative frequency of $\mathrm{CD} 34^{+} \mathrm{CD} 38^{-}$and $\mathrm{CD} 34^{+} \mathrm{DR}^{-}$cells, lineage-committed precursors, and colony-forming units (CFU) in blood and bone marrow and assessed the cell cycle to investigate the effects of maturation and aging on hematopoiesis in healthy rhesus monkeys from fetal through adult life.

CBCs. CBCs all were within normal limits for each respective age group when compared with historical controls $(n=$ 150; data not shown).

CD34 $^{+}$cells. Blood and bone marrow from second- and third-trimester fetuses, newborns, infants, adults, and aged monkeys were immunostained with CD34 MAb, and the relative frequency of $\mathrm{CD} 34^{+}$cells was measured using flow cytometry (Fig. 1). A higher frequency of circulating CD34 ${ }^{+}$ cells was observed in second-trimester fetuses $(4.99 \pm 0.16 \%)$ when compared with third-trimester fetuses $(2.55 \pm 0.09 \%$; $120 \mathrm{~d} ; p<0.05)$ and newborns $(0.79 \pm 0.08 \%)$. The quantity of $\mathrm{CD} 34^{+}$cells then remained relatively stable in infants $(0.98$ $\pm 0.07 \%)$, adults $(0.82 \pm 0.07 \%)$, and aged animals (0.59 \pm $0.05 \% ; p>0.05)$. In contrast to blood, a steady increase in 


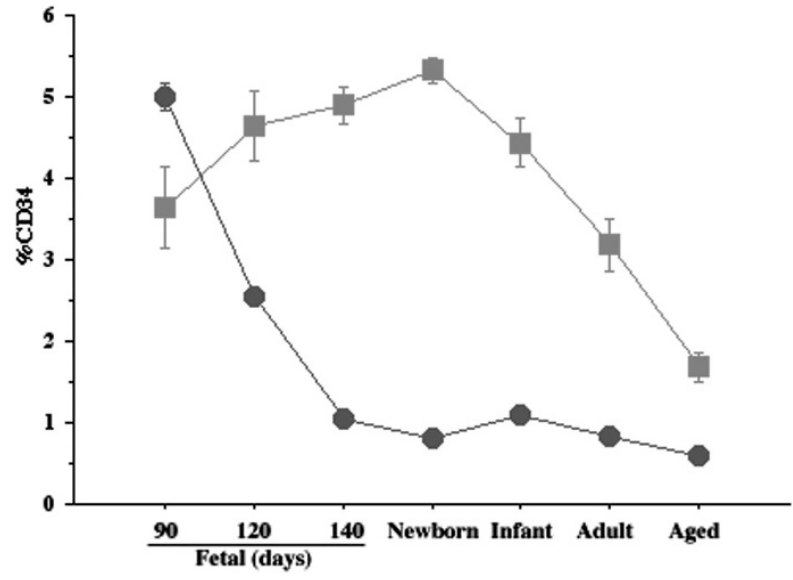

Figure 1. Frequency of $\mathrm{CD} 34^{+}$cells. MNCs from blood and bone marrow were stained with $\mathrm{CD} 34 \mathrm{IgG}_{1}-\mathrm{PE}$, and $\mathrm{CD} 34^{+}$expression was analyzed using flow cytometry. A significantly greater number of circulating $\mathrm{CD} 34^{+}$cells were observed in second-trimester fetuses when compared with all other age groups $(p<0.05)$. A gradual increase in $\mathrm{CD} 34^{+}$cells was seen in second- and third-trimester fetal bone marrow, followed by a decline in adult and aged bone marrow - Blood; $\longrightarrow$ Marrow. $(p<0.05)$.

bone marrow $\mathrm{CD} 34^{+}$cells was observed from the second trimester to birth $(3.65 \pm 0.49 \%, 90 \mathrm{~d} ; 5.33 \pm 0.15 \%$, birth; $p$ $<0.05)$ followed by a decline in infants $(4.43 \pm 0.29 \%)$, adults $(3.19 \pm 0.32 \%)$, and aged animals $(1.68 \pm 0.18 \% ; p<0.05)$. Overall, a significantly higher number $(p<0.05)$ of CD $34^{+}$ cells were observed in bone marrow when compared with blood.

Primitive hematopoietic progenitor cells. We also analyzed the frequency of $\mathrm{CD} 34^{+} \mathrm{CD} 38^{-}$and $\mathrm{CD} 34^{+} \mathrm{DR}^{-}$cells in blood and bone marrow from second- and third-trimester fetuses, newborns, infants, adults, and aged monkeys (Fig. 2). A greater quantity of $\mathrm{CD} 34^{+} \mathrm{CD} 38^{-}$cells was observed in fetal blood (90 and $120 \mathrm{~d}$ gestation; $1.64 \pm 0.09 \%$ ) when compared with the other age groups $(p<0.05$; Fig. 3$)$. In contrast to blood, the highest quantity of $\mathrm{CD} 34^{+} \mathrm{CD} 38^{-}$cells was observed in newborn bone marrow $(3.98 \pm 0.02 \%)$. Approximately $1.5 \%$ of MNCs were $\mathrm{CD} 34^{+} \mathrm{CD} 38^{-}$in adult and aged marrow. In addition, a significantly higher frequency of $\mathrm{CD} 34^{+} \mathrm{DR}^{-}$cells $(2.94 \pm 0.16 \%)$ was observed in second-trimester fetal blood (90 d gestation) when compared with $\mathrm{CD} 34^{+} \mathrm{CD} 38^{-}$cells $(p<$ 0.05 ; Fig. 3). The quantity of circulating $\mathrm{CD} 34^{+} \mathrm{DR}^{-}$and $\mathrm{CD} 34^{+} \mathrm{CD} 38^{-}$cells was similar for the other age groups. A greater quantity of bone marrow $\mathrm{CD} 34^{+} \mathrm{DR}^{-}$cells was observed in fetuses $(3.67 \pm 0.23 \%)$ and infants $(2.58 \pm 0.43 \%)$ when compared with adults $(1.32 \pm 0.26 \% ; p<0.05)$. However, fewer $\mathrm{CD} 34^{+} \mathrm{DR}^{-}$cells were observed in aged bone marrow $(0.25 \pm 0.14 \%)$ when compared with adults $(p<$ $0.05)$. Overall, the relative frequency of $\mathrm{CD} 34^{+} \mathrm{CD} 38^{-}$and $\mathrm{CD} 34^{+} \mathrm{DR}^{-}$cells in bone marrow remained relatively stable in developing monkeys, then declined in adult and aged animals, whereas circulating $\mathrm{CD} 34^{+} \mathrm{CD} 38^{-}$and $\mathrm{CD} 34^{+} \mathrm{DR}^{-}$cells declined during the third trimester and were stable thereafter.

Lineage markers. We assessed the proportion of $\mathrm{CD}^{+}(\mathrm{T}$ lymphoid precursors), $\mathrm{CD}^{+} 4^{+}$(monocytic precursors), and $\mathrm{CD} 20^{+}$(B lymphoid precursors) cells within the CD $34^{+}$immunoselected population to determine the frequency of lin-

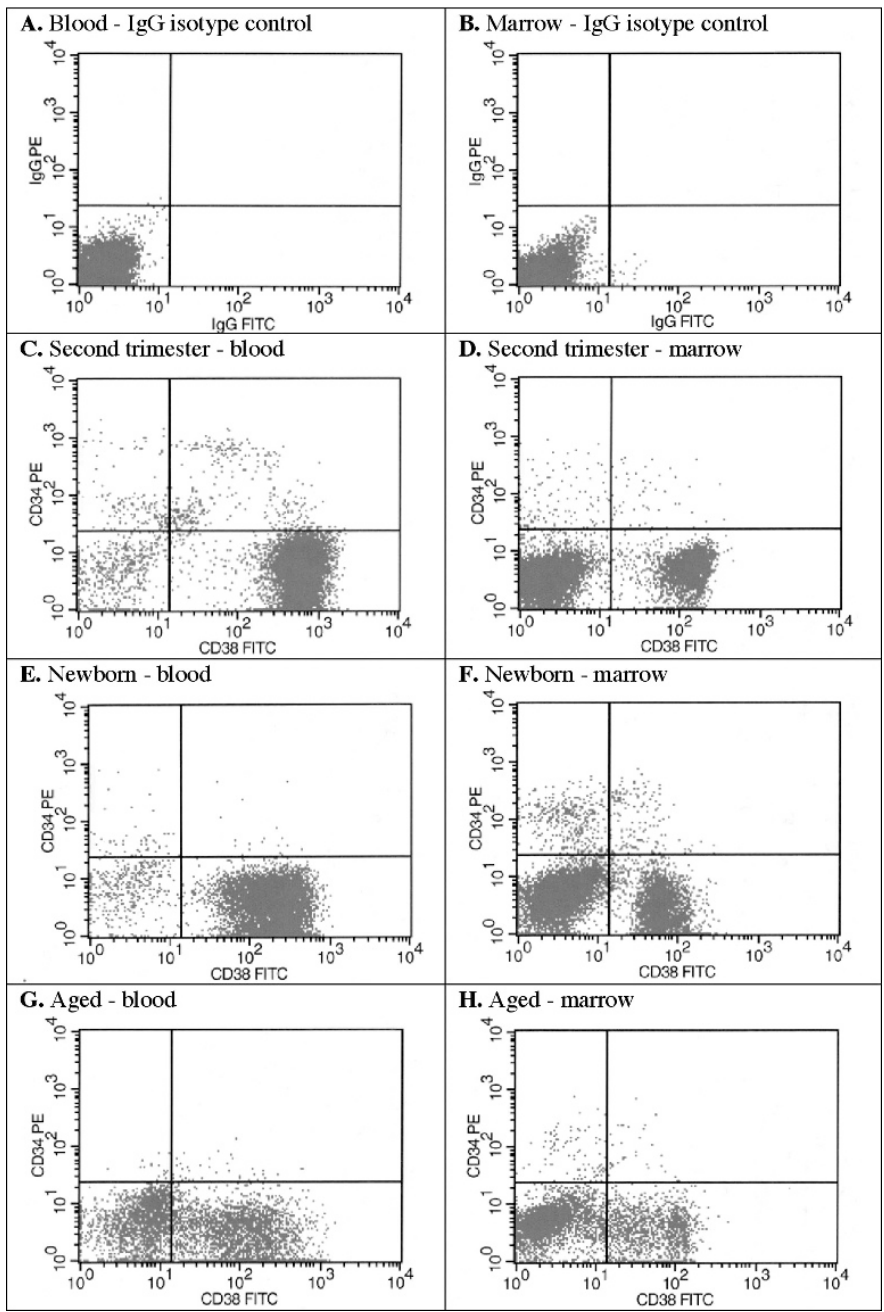

Figure 2. Flow cytometric analysis of $\mathrm{CD} 34^{+} \mathrm{CD} 38^{-}$and $\mathrm{CD} 34^{+} \mathrm{CD} 38^{+}$ cells. MNCs from blood and bone marrow were stained with CD34-PE and CD38-FITC. A higher frequency $(p<0.05)$ of $\mathrm{CD} 34^{+} \mathrm{CD} 38^{-}$cells was observed in second-trimester ( $90 \mathrm{~d}$ gestation) fetal blood $(C)$ when compared with newborns $(E)$ or aged animals $(G)$. In bone marrow, a greater quantity of cells was observed in newborns $(F)$ when compared with second-trimester fetuses $(D)$ or aged animals $(H)$. Blood $(A)$ and bone marrow $(B)$ were also stained with appropriate isotype controls.

eage-committed hematopoietic progenitor cells (Fig. 4). A significantly lower proportion of $\mathrm{CD} 34^{+} \mathrm{CD}^{+}$cells in secondtrimester fetal blood were found $(18.66 \pm 5.10 \%)$ when compared with newborns $(63.22 \pm 7.61 \%)$ and adults $(61.76 \pm$ $10.48 \% ; p<0.05)$. However, the proportion of $\mathrm{CD} 34^{+} \mathrm{CD}^{+}$ cells was significantly lower in aged animals $(46.40 \pm 4.57 \%)$ when compared with infants $(57.89 \pm 4.64 \% ; p<0.05)$. Similarly, the proportion of circulating $\mathrm{CD} 34^{+} \mathrm{CD} 14^{+}$cells in second-trimester fetuses $(19.01 \pm 1.34 \%)$ was significantly lower than that found in third-trimester fetuses (46.61 \pm $6.02 \%)$ and adults $(44.18 \pm 10.07 \% ; p<0.05)$. A significant decline in the frequency of $\mathrm{CD} 34^{+} \mathrm{CD} 14^{+}$cells was observed in aged animals $(24.21 \pm 5.14 \% ; p<0.05)$. A greater quantity of circulating $\mathrm{CD} 34^{+} \mathrm{CD} 20^{+}$cells were found in infants (14.58 $\pm 2.62 \%)$ and adults $(11.74 \pm 0.38 \%)$ when compared with fetuses $(2.84 \pm 0.38 \% ; p<0.05)$. The proportion of $\mathrm{CD}^{+}$, $\mathrm{CD} 14^{+}$, and $\mathrm{CD} 20^{+}$cells within the $\mathrm{CD} 34^{+}$populations in 


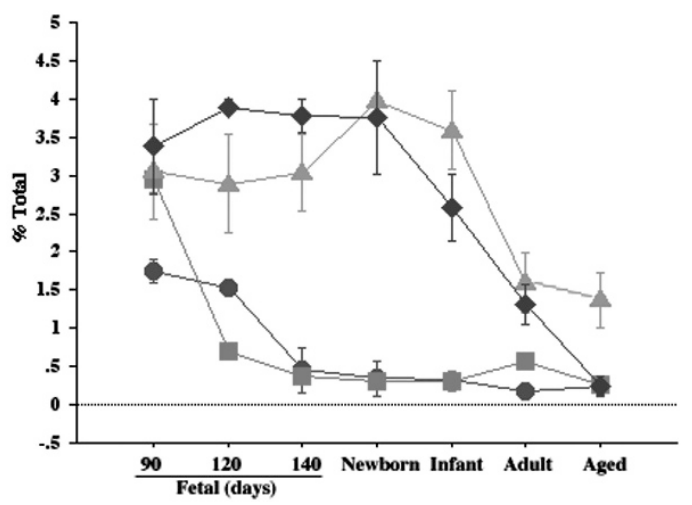

Figure 3. $\mathrm{CD} 34+\mathrm{CD} 38^{-}$and $\mathrm{CD} 34^{+} \mathrm{DR}^{-}$cells in blood and marrow. $\mathrm{CD} 34^{+} \mathrm{CD} 38^{-}$and $\mathrm{CD} 34^{+} \mathrm{DR}^{-}$cells were analyzed by flow cytometry. The frequency of $\mathrm{CD} 34^{+} \mathrm{CD} 38^{-}$cells decreased in adult and aged bone marrow when compared with younger animals. A significantly higher quantity of $\mathrm{CD} 34^{+} \mathrm{CD} 38^{-}$cells were observed in fetal blood at 90 and $120 \mathrm{~d}$ gestation when compared with the other age groups $(p<0.05)$. A higher frequency of $\mathrm{CD} 34^{+} \mathrm{DR}^{-}$cells were observed in fetal blood at $90 \mathrm{~d}$ gestation compared with older animals. The frequency of $\mathrm{CD} 34^{+} \mathrm{DR}^{-}$cells was also higher in bone marrow from fetuses and newborns when compared with the other age groups. - Blood, CD34+CD38 $;-$ Blood, CD34+DR ${ }^{-} ; \boldsymbol{\Lambda}$ Marrow, $\mathrm{CD} 34+\mathrm{CD}^{-} 8^{-} ;-$Marrow, $\mathrm{CD} 38+\mathrm{DR}^{-}$.

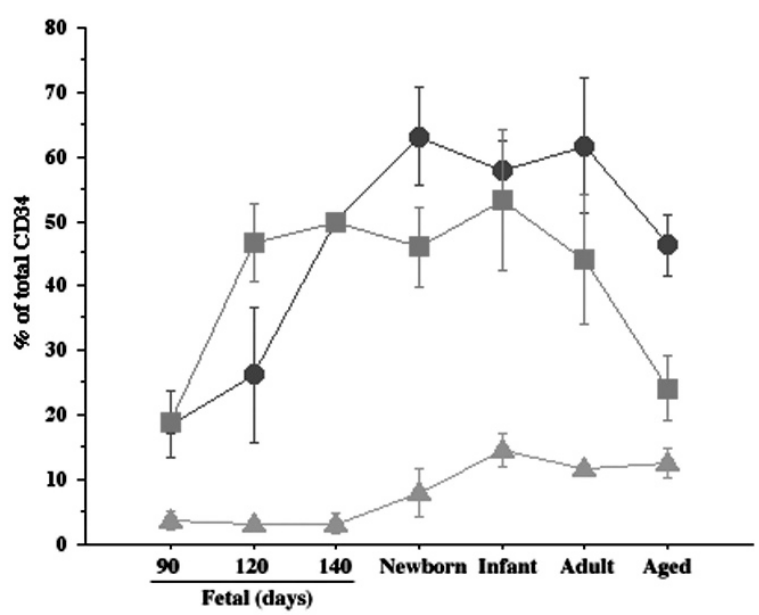

Figure 4. Lineage markers. $\mathrm{CD} 34^{+} \mathrm{CD}^{+}$(T lymphoid precursors; circles), $\mathrm{CD} 34^{+} \mathrm{CD} 14^{+}$(monocytic precursors; squares), and $\mathrm{CD} 34^{+} \mathrm{CD} 20^{+}$(B lymphoid precursors; triangles) cells were analyzed by flow cytometry. The frequencies of $\mathrm{CD} 34^{+} \mathrm{CD} 3{ }^{+}$and $\mathrm{CD} 34^{+} \mathrm{CD} 14^{+}$cells increased significantly during the third trimester $(p<0.05)$. However, a significantly lower quantity of $\mathrm{CD}_{3} 4^{+} \mathrm{CD}_{3}{ }^{+}$and $\mathrm{CD} 34^{+} \mathrm{CD} 14^{+}$cells were observed in blood from aged animals when compared with newborns and infants $(p<0.05)$. A significantly higher number of circulating $\mathrm{CD} 34^{+} \mathrm{CD} 20^{+}$cells were observed in infants, adults, and aged animals when compared with fetuses $(p<0.05)$.

bone marrow of adults was significantly higher when compared with younger animals $(p<0.05$; data not shown).

Cell cycle. Immunoselected $\mathrm{CD} 34^{+}$cells from blood and bone marrow were stained with propidium iodide, and DNA content was analyzed using ModFit software. Cellular debris and aggregates were excluded from the analysis by gating (Fig. 5). These studies revealed that $\geq 94 \%$ of circulating CD $34^{+}$ cells were quiescent in third-trimester fetuses $(120$ and $140 \mathrm{~d}$ gestation), newborns, infants, adult, and aged animals (Table 2). The frequency of $90-\mathrm{d}$ fetal blood $\mathrm{CD} 34^{+}$cells entering the $\mathrm{G}_{2} / \mathrm{M}$ phase of the cell cycle was significantly greater than cells from newborn, infant, adult, and aged animals $(p<0.05)$. In contrast, $\geq 20 \%$ of bone marrow $\mathrm{CD} 34^{+}$cells from most age groups were observed at the $S / G_{2} / M$ phase. The quantity of marrow $\mathrm{CD} 34^{+}$cells that was obtained from 90 -d fetuses in the $\mathrm{S}$ phase $(28.81 \pm 3.86 \%)$ was significantly higher when compared with aged animals $(14.45 \pm 0.34 \% ; p<0.05)$. Overall, the frequency of cycling $\mathrm{CD} 34^{+}$cells gradually declined with maturation and aging (Table 2).

Hematopoietic progenitors. To assess the effects of aging on the quantity of hematopoietic progenitors, MNCs from blood and bone marrow from fetal $(90,120,140 \mathrm{~d}$ gestation), newborn, infant, adult, and aged rhesus monkeys were plated in complete methylcellulose medium, and hematopoietic progenitor colonies were counted after a standard incubation period (22). In second-trimester fetal blood, $12.00 \pm 4.00$ burstforming unit-erythroid (BFU-E) per $3 \times 10^{5}$ total MNCs were observed in the peripheral circulation (Fig. 6A), whereas very few colonies were found in newborn, infant, adult, or aged animals. Significantly higher numbers of erythroid and myeloid progenitors were observed in bone marrow when compared with blood. Analysis of second-trimester fetal bone marrow revealed $32.67 \pm 2.19 \mathrm{BFU}-\mathrm{E}$ per $8 \times 10^{4} \mathrm{MNCs}$, whereas $17.01 \pm 5.01$ and $7.50 \pm 4.98 \mathrm{BFU}-\mathrm{E}$ were observed in 120- and 140-d fetal bone marrow, respectively. A significant increase in the frequency of erythroid progenitors was observed in aged bone marrow $(39.01 \pm 7.37)$ when compared with third-trimester fetal bone marrow $(p<0.05)$. In contrast, a greater quantity of myeloid progenitors was observed in second-trimester fetal bone marrow $(199.00 \pm 84.34)$ when compared with aged bone marrow $(17.00 \pm 1.53$; Fig. $6 B)$. In the peripheral circulation, a significantly higher quantity of myeloid progenitors was observed in second-trimester fetal blood (134.00 \pm 24.58$)$ when compared with infants (4.40 \pm $1.09 ; p<0.05)$. Very few colonies were observed in culture when grown from blood samples that were obtained from adult or aged animals.

\section{DISCUSSION}

We have demonstrated a decline in the frequency of bone marrow $\mathrm{CD} 34^{+} \mathrm{CD} 38^{-}$and $\mathrm{CD} 34^{+} \mathrm{DR}^{-}$cells with advancing age in rhesus monkeys. The relative quantity of myeloid progenitors was also found to decrease with aging, although the relative quantity of erythroid progenitors increased in older animals. A significantly higher number of $\mathrm{CD} 34^{+}$cells in the $\mathrm{G}_{2} / \mathrm{M}$ phase were found in bone marrow when compared with the peripheral circulation in all age groups $(p=0.001)$.

The transition from fetal to adult hematopoiesis occurs in fetal liver and bone marrow, where a large and expanding pool of multipotent hematopoietic cells emerge during middle to late gestation $(24,25)$. The migration and homing of HSCs from fetal liver to bone marrow during the second and early third trimesters of pregnancy have been proposed to be controlled by adhesion molecules, such as integrins $(25,26)$. Studies have assessed migrating or newly resident cells in hematopoietic organs both quantitatively and qualitatively using immunophenotypic and CFU assays (27), and human fetal blood has been shown to contain high quantities of hemato- 


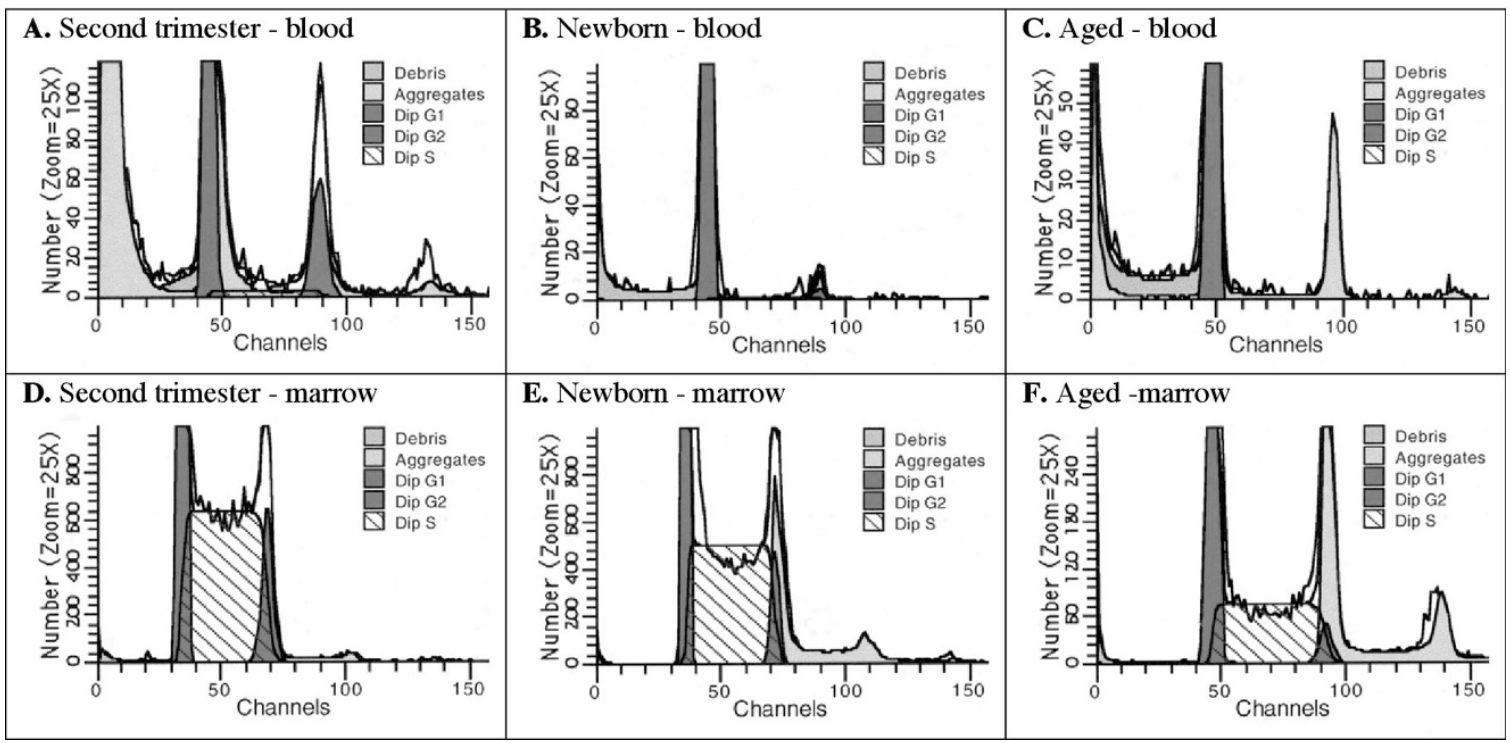

Figure 5. Cell cycle. Double-immunoselected $\mathrm{CD} 34^{+}$cells from blood and bone marrow were stained with propidium iodide. DNA content was measured by flow cytometry. The frequency of cells within the $\mathrm{G}_{0} / \mathrm{G}_{1}, \mathrm{~S}$, and $\mathrm{G}_{2} / \mathrm{M}$ phases was determined using ModFit software. Both cellular debris and aggregates were excluded from the analysis by gating. The frequency of $\mathrm{CD} 34^{+}$cells entering the $\mathrm{S} / \mathrm{G}_{2} / \mathrm{M}$ phase was higher in second-trimester fetuses $(A)$ when compared with $\mathrm{CD}_{3} 4^{+}$cells from newborn $(B)$ or aged $(C)$ animals. Fewer numbers of cycling CD34 ${ }^{+}$cells were observed in newborn $(E)$ or aged $(F)$ bone marrow when compared with second-trimester fetuses $(D)$.

Table 2. $\mathrm{CD} 34^{+}$cell cycle analysis

\begin{tabular}{|c|c|c|c|c|}
\hline Age & Sample & $\mathrm{G}_{0} / \mathrm{G}_{1}$ & $S$ & $\mathrm{G}_{2} / \mathrm{M}$ \\
\hline \multirow[t]{2}{*}{$90 d^{*}$} & Blood & $89.63 \pm 1.94$ & $5.20 \pm 1.10$ & $5.17 \pm 2.29$ \\
\hline & Marrow & $66.85 \pm 3.91$ & $28.81 \pm 3.86$ & $4.34 \pm 0.46$ \\
\hline $120 \mathrm{~d}^{*}$ & Blood & $94.45 \pm 2.58$ & $1.44 \pm 0.46$ & $4.11 \pm 2.13$ \\
\hline \multirow[t]{2}{*}{$140 \mathrm{~d}^{*}$} & Blood & $95.22 \pm 3.89$ & $1.70 \pm 1.06$ & $3.01 \pm 2.82$ \\
\hline & Marrow & $72.80 \pm 2.75$ & $23.48 \pm 1.83$ & $3.72 \pm 1.49$ \\
\hline Newborn & Blood $\dagger$ & $97.28 \pm 0.81$ & $1.13 \pm 0.39$ & $1.44 \pm 0.88$ \\
\hline Infant & Marrow & $75.38 \pm 2.10$ & $20.68 \pm 2.93$ & $4.26 \pm 0.54$ \\
\hline \multirow[t]{2}{*}{ Adult } & Blood & $95.24 \pm 1.65$ & $4.25 \pm 1.85$ & $0.51 \pm 0.23$ \\
\hline & Marrow & $77.03 \pm 1.76$ & $20.02 \pm 1.52$ & $2.95 \pm 0.48$ \\
\hline \multirow[t]{2}{*}{ Aged } & Blood & $99.42 \pm 0.22$ & $0.40 \pm 0.11$ & $0.18 \pm 0.16$ \\
\hline & Marrow & $82.97 \pm 1.22$ & $14.45 \pm 0.34 \ddagger$ & $1.69 \pm 0.34$ \\
\hline
\end{tabular}

* Gestational age.

$\dagger$ Umbilical cord blood was analyzed.

$\ddagger p<0.05$ compared to the other age groups.

poietic progenitors (28). Data in rhesus monkeys suggest that the greatest quantity of hematopoietic progenitor and $\mathrm{CD} 34^{+}$ cells can be found in the peripheral circulation during fetal development, whereas a significant decline in the number of these cells occurs in the third trimester, when bone marrow becomes the major site of hematopoiesis (29). Human cord blood has been shown to contain HSCs in sufficient quantity for hematopoietic reconstitution, although the number of MNCs in cord blood is only one tenth of that observed in adult bone marrow (30-33). It has been estimated that the relative proliferative potential of MNCs from cord blood to reconstitute the hematopoietic system is 6-fold higher than cells that are obtained from adult bone marrow and, thus, provides an attractive source of hematopoietic cells for transplant purposes $(33,34)$. However, consistent with reports in human and baboon fetuses $(34,35)$, data in rhesus monkeys suggest that the highest frequency of $\mathrm{CD} 34^{+}$cells is found in fetal blood, and these cells decline significantly toward the end of gestation.

Nonspecific T cell-like immunologic reactivity has been demonstrated in yolk sac, liver, and bone marrow of developing fetuses, although the establishment of mature $\mathrm{T}$ cells depends on the normal growth and development of the thymus $(36,37)$. Cortical and medullary populations of human $\mathrm{T}$ cells in the thymus can be distinguished by 12 wk gestation, and these cells are found in the fetal circulation by $14 \mathrm{wk}$ gestation (36). At term, $\mathrm{T}$ cells can proliferate in response to mitogens at levels comparable to adults (38); we have observed a similar outcome in rhesus monkeys (unpublished observations). In this study, we have shown that the quantity of $\mathrm{CD} 34^{+} \mathrm{CD} 3^{+} \mathrm{T}$ lymphoid precursors increases during the second and third trimesters and reaches adult levels at birth. Although the ability to synthesize antibodies is acquired early in gestation, the 
A

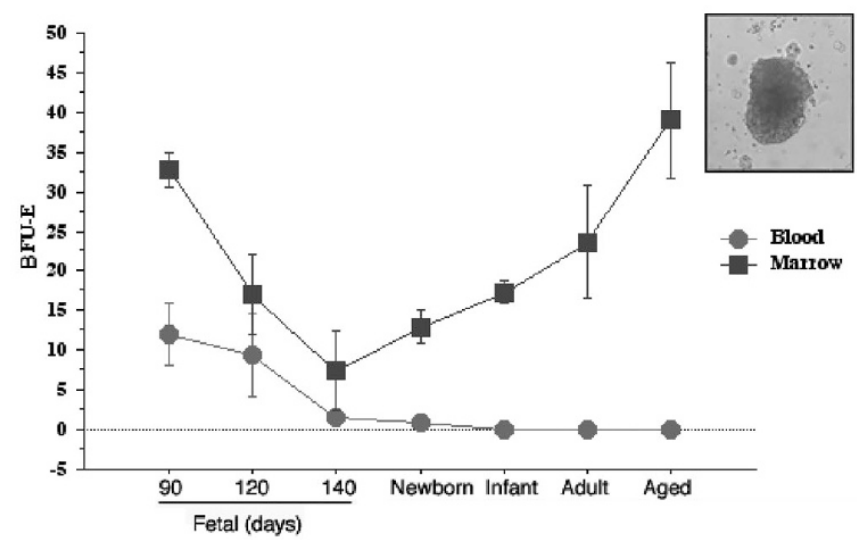

B

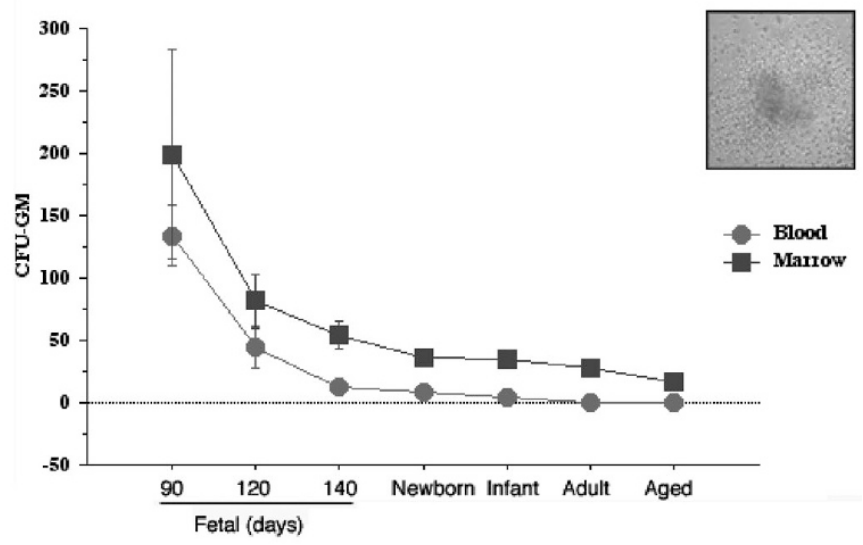

Figure 6. Hematopoietic progenitors. MNCs from blood and bone marrow from the different age groups were plated in methylcellulose medium and incubated for a standard time period (see text). The quantity of blood BFU-E decreased over time, whereas marrow erythroid progenitors decreased during gestation then increased significantly as the animals matured $(A)$. In contrast, the frequency of CFU-granulocyte-macrophage (CFU-GM) decreased in both blood and bone marrow with advancing age $(B)$.

frequency of $\mathrm{CD} 20^{+} \mathrm{B}$ cells does not reach adult levels until $2-3$ mo after birth $(39,40)$. A delay in the production of IL-7 by bone marrow stroma, which is critical in the development of $\mathrm{B}$ cells, may play a role in the late onset of B lymphopoiesis (41). In contrast to lymphoid precursors, the frequency of $\mathrm{CD} 34^{+} \mathrm{CD} 14^{+}$monocytic precursors reaches adult levels at $120 \mathrm{~d}$ gestation in fetal monkeys, similar to human fetuses, suggesting that innate immunity develops much earlier than humoral or cell-mediated immune responses (42).

The majority of circulating CD $34^{+}$cells was noted in the $\mathrm{G}_{0} / \mathrm{G}_{1}$ phase of the cell cycle. These observations are very similar to findings in humans, in whom $<0.5 \%$ of $\mathrm{CD} 34^{+}$cells have been reported in the peripheral circulation and $1-4 \%$ in bone marrow $(33,43-45)$. Our observations also agree with findings in humans, in whom cord blood $\mathrm{CD} 34^{+}$cells have been shown to possess different characteristics when compared with cells that are obtained from fetal or adult bone marrow (33-35,46). During steady-state hematopoiesis, peripheral blood $\mathrm{CD} 34^{+}$cells have been hypothesized to migrate between bone marrow and organs differentially expressing many functional proteins $(47,48)$. Down-regulation of proteins related to the cell cycle has been shown in peripheral blood, whereas these proteins are abundantly expressed in bone marrow $\mathrm{CD} 34^{+}$cells. $\mathrm{CD} 34^{+}$cells from bone marrow have been reported to express nine cell cycle-driving genes and 11 genes that are required for DNA synthesis at distinctly higher levels than $\mathrm{CD} 34^{+}$cells in the peripheral circulation (49). We also observed 30 erythroid and 35 myeloid colonies per $1 \times 10^{5}$ MNCs in adult bone marrow, whereas very few progenitors were observed in the peripheral circulation for all age groups. These observations suggest that blood $\mathrm{CD} 34^{+}$cells are typically quiescent and may require bone marrow stroma for entrance into the cell cycle, which is necessary for hematopoietic proliferation and differentiation $(50,51)$.

Aging of human HSCs has been characterized by the loss of telomeric DNA, which has been proposed to be closely related to the self-renewal potential and senescence of these cells $(52,53)$. Consistent with this finding, Lansdorp et al. (54) reported a marked decrease in the ability to produce CD $34^{+}$ progenitor cells in blood, bone marrow, and fetal liver cultures with advancing donor age. In contrast to findings in humans, HSCs in mice have been reported to accumulate with age, accompanied by reduced lymphoid differentiation potential $(55,56)$. In the rhesus monkey studies described here, the frequency of $\mathrm{CD} 34^{+} \mathrm{CD} 38^{-}$and $\mathrm{CD} 34^{+} \mathrm{DR}^{-}$cells declined with advancing age. CD38 is a $46-\mathrm{kDa}$ type II glycoprotein that is strongly expressed on the cell surface of lymphoid progenitor cells and also weakly expressed on mature $\mathrm{T}$ and $\mathrm{B}$ lymphocytes, monocytes, granulocytes, natural killer cells, and plasma cells (57-61). HLA-DR is also a transmembrane glycoprotein expressed primarily on antigen-presenting cells (B cells, monocytes, macrophages, and thymic epithelial cells) and activated T cells (62). Both CD38 and HLA-DR have been used to distinguish primitive hematopoietic progenitor cells from more mature cells within the $\mathrm{CD} 34^{+}$population. However, CD $34^{+} \mathrm{DR}^{-}$cells that were obtained from mobilized peripheral blood and fetal liver have been shown to contain both erythroid and myeloid progenitor cells, whereas the $\mathrm{CD} 34^{+} \mathrm{CD} 38^{-}$population contains only myeloid progenitor cells. These data suggest that the $\mathrm{CD} 34^{+} \mathrm{DR}^{-}$population may represent more primitive hematopoietic progenitor cells, although a definitive functional assay would be required to elucidate any differences $(63,64)$. A significant decline in marrow $\mathrm{CD} 34^{+} \mathrm{DR}^{-}$cells in aged animals was found when compared with $\mathrm{CD} 34^{+} \mathrm{CD} 38^{-}$cells $(p<0.05)$ and may indicate a further decline in the frequency of more primitive hematopoietic progenitor cells with advancing age.

Studies also revealed that the frequency of $\mathrm{CD} 34^{+}$cells entering the cell cycle decreases with advancing age, whereas most $\mathrm{CD} 34^{+}$cells in the peripheral circulation remained at the $\mathrm{G}_{0} / \mathrm{G}_{1}$ phase for all ages evaluated. These results suggest that the self-renewal capabilities of $\mathrm{CD} 34^{+}$cells may diminish with aging in rhesus monkeys. An accumulation of intracellular damage leading to apoptosis and decreased efficiency in the marrow microenvironment are hypothesized to explain the age-related changes in HSCs in humans (65). Our findings also suggest that fewer myeloid progenitors are observed in older animals when compared with younger animals. Consistent with this observation, the frequency of $\mathrm{CD} 34^{+} \mathrm{CD} 3^{+} \mathrm{T}$ lymphoid 
and $\mathrm{CD} 34^{+} \mathrm{CD} 14^{+}$monocytic precursors also decline with advancing age and is accompanied by a decrease of cells in the $\mathrm{G}_{2} / \mathrm{M}$ phase of the cell cycle, as noted above. These findings are consistent with studies that have described the agedependent decline in immune competence and host response to infectious and inflammatory stimuli in both humans and animals (66-68). Although the findings in this study indicate that the concentration of $\mathrm{CD} 34^{+} \mathrm{CD} 20^{+} \mathrm{B}$ lymphoid precursors are shown to be maintained at a similar level in aged animals when compared with younger individuals, further functional assays are necessary to demonstrate the effects of aging on the immune system. However, greater quantities of erythroid progenitors were found in adult and aged animals, which may be explained by a compensatory response to the increased removal of erythrocytes observed in older individuals $(69,70)$. This compensatory response may be crucial in maintaining a sufficient quantity of erythrocytes in the peripheral circulation with advancing age, which is more similar to findings in early-, rather than late-, gestation fetuses (34).

\section{CONCLUSION}

In summary, these studies have shown that the greatest quantity of primitive hematopoietic progenitor cells can be found in third-trimester fetal and infant rhesus monkey bone marrow and that entry of $\mathrm{CD} 34^{+}$cells into the cell cycle gradually declines with aging. Similar to findings in humans and baboons $(34,35,71,72)$, these results suggest that bone marrow $\mathrm{CD} 34^{+}$cells from young rhesus monkeys retain higher self-renewal and proliferative potential than those obtained from older animals. The rhesus monkey model will be crucial for assessing differences in stem cell biology with advancing age and for exploring unique needs that may arise in the use of cell- and gene-based therapies in older compared with younger individuals.

Acknowledgments. We thank the animal care and clinical laboratory staff at the California National Primate Research Center for expert technical assistance and Will Cuper for manuscript review.

\section{REFERENCES}

1. Hayflick L 1965 The limited in vitro lifetime of human diploid cell strains. Exp Cell Res 37:614-636

2. Martin GM, Sprague CA, Epstein CJ 1970 Replicative life-span of cultivated human cells. Effects of donor's age, tissue, and genotype. Lab Invest 23:86-92

3. Andrews RG, Winkler A, Potter J, Bryant E, Knitter GH, Bernstein ID, Ochs HD 1997 Normal immunologic response to a neoantigen, bacteriophage phiX-174, in baboons with long-term lymphohematopoietic reconstitution from highly purified $\mathrm{CD}^{+}{ }^{+}$Lin-allogeneic marrow cells. Blood 90:1701-1708

4. Morrison SJ, Weissman IL 1994 The long-term repopulating subset of hematopoietic stem cells is deterministic and isolatable by phenotype. Immunity 1:661-673

5. Harrison DE, Astle CM, Stone M 1989 Numbers and functions of transplantable primitive immunohematopoietic stem cells. Effects of age. J Immunol 142:3833-3840

6. Andrews RG, Briddell RA, Knitter GH, Rowley SD, Appelbaum FR, McNiece IK 1995 Rapid engraftment by peripheral blood progenitor cells mobilized by recombinant human stem cell factor and recombinant human granulocyte colony-stimulating factor in nonhuman primates. Blood 85:15-20

7. Harrison DE 1983 Long-term erythropoietic repopulating ability of old, young, and fetal stem cells. J Exp Med 157:1496-1504

8. Harrison DE, Zhong RK, Jordan CT, Lemischka IR, Astle CM 1997 Relative to adult marrow, fetal liver repopulates nearly five times more effectively long-term than short-term. Exp Hematol 25:293-297
9. Micklem HS, Ford CE, Evans EP, Ogden DA, Papworth DS 1972 Competitive in vivo proliferation of foetal and adult hematopoietic cells in lethally irradiated mice. J Cell Physiol 79:293-298

10. Rebel VI, Miller CL, Eaves CJ, Lansdorp PM 1996 The repopulation potential of fetal liver hematopoietic stem cells in mice exceeds that of their liver adult bone marrow counterparts. Blood 87:3500-3507

11. Rebel VI, Miller CL, Thornbury GR, Dragowska WH, Eaves CJ, Lansdorp PM 1996 A comparison of long-term repopulating hematopoietic stem cells in fetal liver and adult bone marrow from the mouse. Exp Hematol 24:638-648

12. Allsopp RC, Weissman IL 2002 Replicative senescence of hematopoietic stem cells during serial transplantation: does telomere shortening play a role? Oncogene 21:3270-3273

13. Harrison DE, Astle CM 1982 Loss of stem cell repopulating ability upon transplantation. Effects of donor age, cell number, and transplantation procedure. J Exp Med 156:1767-1779

14. Harrison DE, Astle CM, Delaittre JA 1978 Loss of proliferative capacity in immunohemopoietic stem cells caused by serial transplantation rather than aging. J Exp Med 147:1526-1531

15. Abkowitz JL, Golinelli D, Harrison DE, Guttorp P 2000 In vivo kinetics of murine hemopoietic stem cells. Blood 96:3399-3405

16. Abkowitz JL, Persik MT, Shelton GH, Ott RL, Kiklevich JV, Catlin SN, Guttorp P 1995 Behavior of hematopoietic stem cells in a large animal. Proc Natl Acad Sci USA 92:2031-2035

17. Andrews RG, Bensinger WI, Knitter GH, Bartelmez SH, Longin K, Bernstein ID, Appelbaum FR, Zsebo KM 1992 The ligand for c-kit, stem cell factor, stimulates the circulation of cells that engraft lethally irradiated baboons. Blood 80:2715-2720

18. Brandt JE, Bartholomew AM, Fortman JD, Nelson MC, Bruno E, Chen LM, Turian JV, Davis TA, Chute JP, Hoffman R 1999 Ex vivo expansion of autologous bone marrow CD34 $(+)$ cells with porcine microvascular endothelial cells results in a graft capable of rescuing lethally irradiated baboons. Blood 94:106-113

19. Cheshier SH, Morrison SJ, Liao X, Weissman IL 1999 In vivo proliferation and cell cycle kinetics of long-term self-renewing hematopoietic stem cells. Proc Natl Acad Sci USA 96:3120-3125

20. Mahmud N, Devine SM, Weller KP, Parmar S, Sturgeon C, Nelson MC, Hewett T, Hoffman R 2001 The relative quiescence of hematopoietic stem cells in nonhuman primates. Blood 97:3061-3068

21. Tarantal AF, Hendrickx AG 1988 Use of ultrasound for early pregnancy detection in the rhesus and cynomolgus macaque (Macaca mulatta and Macaca fascicularis). J Med Primatol 17:105-112

22. Tarantal AF, Goldstein O, Barley F, Cowan MJ 2000 Transplantation of human peripheral blood stem cells into fetal rhesus monkeys (Macaca mulatta). Transplantation $69: 1818-1823$

23. Tarantal AF, Gargosky SE, Ellis DS, O'Brien WD Jr, Hendrickx AG 1995 Hematologic and growth-related effects of frequent prenatal ultrasound exposure in the long-tailed macaque (Macaca fascicularis). Ultrasound Med Biol 21:1073-1081

24. Ikuta K, Kina T, MacNeil I, Uchida N, Peault B, Chien YH, Weissman IL 1990 A developmental switch in thymic lymphocyte maturation potential occurs at the level of hematopoietic stem cells. Cell 62:863-874

25. Morrison SJ, Uchida N, Weissman IL 1995 The biology of hematopoietic stem cells. Annu Rev Cell Dev Biol 11:35-71

26. Corbel C, Salaun J $2002 \alpha \mathrm{IIb}$ integrin expression during development of the murine hemopoietic system. Dev Biol 243:301-311

27. Poznansky MC, Olszak IT, Foxall RB, Piascik A, Adams GB, Evans RH, Cheng T, Scadden DT 2001 Tissue source dictates lineage outcome of human fetal CD34(+)CD38(-) cells. Exp Hematol 29:766-774

28. Christensen RD 1989 Hematopoiesis in the fetus and neonate. Pediatr Res 26:531535

29. Campagnoli C, Fisk N, Overton T, Bennett P, Watts T, Roberts I 2000 Circulating hematopoietic progenitor cells in first trimester fetal blood. Blood 95:1967-1972

30. Wagner JE, Kernan NA, Steinbuch M, Broxmeyer HE, Gluckman E 1995 Allogeneic sibling umbilical-cord-blood transplantation in children with malignant and nonmalignant disease. Lancet 346:214-219

31. Gluckman E, Thierry D, Lesage S, Traineau R, Gerotta J, Rabian C, Brossard Y, Van Nifterik J, Benbunan M 1992 Cord blood banking for human hematopoietic cell transplantation. Prog Clin Biol Res 377:591-598; discussion 599-602

32. Rubinstein P, Rosenfield RE, Adamson JW, Stevens CE 1993 Stored placental blood for unrelated bone marrow reconstitution. Blood 81:1679-1690

33. Huang S, Law P, Young D, Ho AD 1998 Candidate hematopoietic stem cells from fetal tissues, umbilical cord blood vs. adult bone marrow and mobilized peripheral blood. Exp Hematol 26:1162-1171

34. Shields LE, Andrews RG 1998 Gestational age changes in circulating CD $34^{+}$ hematopoietic stem/progenitor cells in fetal cord blood. Am J Obstet Gynecol 178:931-937

35. Haneline LS, Marshall KP, Clapp DW 1996 The highest concentration of primitive hematopoietic progenitor cells in cord blood is found in extremely premature infants. Pediatr Res 39:820-825

36. Kay HE, Playfair JH, Wolfendale M, Hopper PK 1962 Development of the thymus in the human foetus and its relation to immunological potential. Nature 196:238-240

37. Stites DP, Carr MC, Fudenberg HH 1975 Ontogeny of cellular immunity in man. Birth Defects Orig Artic Ser 11:489-493

38. Hayward AR 1981 Development of lymphocyte responses and interactions in the human fetus and newborn. Immunol Rev 57:39-60

39. DeMaria MA, Castro M, O'Connell M, Johnson RP, Rosenzweig M 2000 Characterization of lymphocyte subsets in rhesus macaques during the first year of life. Eur J Haematol 65:245-257 
40. Burgio GR, Ugazio AG, Notarangelo LD 1989-1990 Immunology of the neonate. Curr Opin Immunol 2:770-777

41. Monroe JG, Allman D 2004 Keeping track of pro-B cells: a new model for the effects of IL-7 during B cell development. Eur J Immunol 34:2642-2646

42. van Furth R, Sluiter W 1983 Current views on the ontogeny of macrophages and the humoral regulation of monocytopoiesis. Trans R Soc Trop Med Hyg 77:614-619

43. Loken MR, Shah VO, Dattilio KL, Civin CI 1987 Flow cytometric analysis of human bone marrow: I. Normal erythroid development. Blood 69:255-263

44. Civin CI, Banquerigo ML, Strauss LC, Loken MR 1987 Antigenic analysis of hematopoiesis. VI. Flow cytometric characterization of My-10-positive progenito cells in normal human bone marrow. Exp Hematol 15:10-17

45. Koenig JM, Luttge B, Benson NA, Christensen RD 2001 Cell cycle status of CD34+ cells in human fetal bone marrow. Early Hum Dev 65:159-163

46. Traycoff CM, Abboud MR, Laver J, Clapp DW, Hoffman R, Law P, Srour EF 1994 Human umbilical cord blood hematopoietic progenitor cells: are they the same as their adult bone marrow counterparts? Blood Cells 20:382-390; discussion 390-391

47. Kronenwett R, Martin S, Haas R 2000 The role of cytokines and adhesion molecules for mobilization of peripheral blood stem cells. Stem Cells 18:320-330

48. Mohle R, Bautz F, Rafii S, Moore MA, Brugger W, Kanz L 1998 The chemokine receptor CXCR-4 is expressed on CD34+ hematopoietic progenitors and leukemic cells and mediates transendothelial migration induced by stromal cell-derived factor-1. Blood 91:4523-4530

49. Steidl U, Kronenwett R, Rohr UP, Fenk R, Kliszewski S, Maercker C, Neubert P, Aivado M, Koch J, Modlich O, Bojar H, Gattermann N, Haas R 2002 Gene expression profiling identifies significant differences between the molecular phenotypes of bone marrow-derived and circulating human $\mathrm{CD} 34+$ hematopoietic stem cells. Blood 99:2037-2044

50. Bagby GC 1987 Production of multilineage growth factors by hematopoietic stroma cells: an intercellular regulatory network involving mononuclear phagocytes and interleukin-1. Blood Cells 13:147-159

51. Bianco P, Riminucci M, Gronthos S, Robey PG 2001 Bone marrow stromal stem cells: nature, biology, and potential applications. Stem Cells 19:180-192

52. Rufer N, Brummendorf TH, Kolvraa S, Bischoff C, Christensen K, Wadsworth L, Schulzer M, Lansdorp PM 1999 Telomere fluorescence measurements in granulocytes and $\mathrm{T}$ lymphocyte subsets point to a high turnover of hematopoietic stem cells and memory T cells in early childhood. J Exp Med 190:157-167

53. Vaziri H, Dragowska W, Allsopp RC, Thomas TE, Harley CB, Lansdorp PM 1994 Evidence for a mitotic clock in human hematopoietic stem cells: loss of telomeric DNA with age. Proc Natl Acad Sci USA 91:9857-9860

54. Lansdorp PM, Dragowska W, Mayani H 1993 Ontogeny-related changes in proliferative potential of human hematopoietic cells. J Exp Med 178:787-791

55. de Haan G, Van Zant G 1999 Dynamic changes in mouse hematopoietic stem cell numbers during aging. Blood 93:3294-3301

56. Sudo K, Ema H, Morita Y, Nakauchi H 2000 Age-associated characteristics of murine hematopoietic stem cells. J Exp Med 192:1273-1280
57. Bhan AK, Nadler LM, Stashenko P, McCluskey RT, Schlossman SF 1981 Stages of B cell differentiation in human lymphoid tissue. J Exp Med 154:737-749

58. Jackson DG, Bell JI 1990 Isolation of a cDNA encoding the human CD38 (T10) molecule, a cell surface glycoprotein with an unusual discontinuous pattern of expression during lymphocyte differentiation. J Immunol 144:2811-2815

59. Janossy G, Tidman N, Papageorgiou ES, Kung PC, Goldstein G 1981 Distribution of T lymphocyte subsets in the human bone marrow and thymus: an analysis with monoclonal antibodies. J Immunol 126:1608-1613

60. Kishimoto H, Hoshino S, Ohori M, Kontani K, Nishina H, Suzawa M, Kato S, Katada T 1998 Molecular mechanism of human CD38 gene expression by retinoic acid. Identification of retinoic acid response element in the first intron. $J$ Biol Chem 273:15429-15434

61. Terstappen LW, Hollander Z, Meiners H, Loken MR 1990 Quantitative comparison of myeloid antigens on five lineages of mature peripheral blood cells. J Leukoc Biol 48:138-148

62. Barclay NA, Birkeland ML, Brown MH 1993 The Leucocyte Antigen Facts Book. Academic Press, San Diego, pp 376

63. Sakabe H, Ohmizono Y, Tanimukai S, Kimura T, Mori KJ, Abe T, Sonoda Y 1997 Functional differences between subpopulations of mobilized peripheral blood-derived CD34+ cells expressing different levels of HLA-DR, CD33, CD38 and c-kit antigens. Stem Cells 15:73-81

64. Muench MO, Cupp J, Polakoff J, Roncarolo MG 1994 Expression of CD33, CD38, and HLA-DR on CD34+ human fetal liver progenitors with a high proliferative potential. Blood 83:3170-3181

65. Van Zant G, Liang Y 2003 The role of stem cells in aging. Exp Hematol 31:659-672

66. Thoman ML, Weigle WO 1989 The cellular and subcellular bases of immunosenescence. Adv Immunol 46:221-261

67. Sadeghi HM, Schnelle JF, Thoma JK, Nishanian P, Fahey JL 1999 Phenotypic and functional characteristics of circulating monocytes of elderly persons. Exp Gerontol 34:959-970

68. Hulstaert F, Hannet I, Deneys V, Munhyeshuli V, Reichert T, De Bruyere M, Strauss K 1994 Age-related changes in human blood lymphocyte subpopulations. II. Varying kinetics of percentage and absolute count measurements. Clin Immunol Immunopathol 70:152-158

69. Biondi C, Cotorruelo C, Garcia Borras S, Rocca L, Ensinck A, Marini A, Racca A 2003 Study of phagocytosis of senescent erythrocytes in young and elderly individuals. Clin Exp Med 2:197-198

70. Tyan ML 1982 Age-related increase in erythrocyte oxidant sensitivity. Mech Ageing Dev 20:25-32

71. Shields LE, Kiem HP, Andrews RG 2000 Highly efficient gene transfer into preterm CD34 hematopoietic progenitor cells. Am J Obstet Gynecol 183:732-737

72. Winkler A, Kiem HP, Shields LE, Sun QH, Andrews RG 1999 Gene transfer into fetal baboon hematopoietic progenitor cells. Hum Gene Ther 10:667-677 